\title{
THEORETICAL IMPACT OF ENHANCED MUSHARAKAH MUTANAQISAH HOME FINANCING ON REAL ESTATE PRICES
}

\author{
Alam I. Asadov ${ }^{1}$ \\ Mansor H. Ibrahim ${ }^{2}$
}

\begin{abstract}
$^{3}$
This paper theoretically analyzes two alternative modes of home financing. The first mode is the conventional housing loan and the other is Enhanced Musharakah Mutanaqisah (EMM) home financing. Our results reveal the EMM based setting is superior to the conventional housing loans in at least two aspects. These are the prevention of house price inflation in all phases of economic business cycle and the smoothening of real estate cycles. This means that, under the EMM, the risk of real estate bubble formation is subdued, which should prove to be welfare improving.
\end{abstract}

Keywords: Musharakah Mutanaqisah, Islamic home financing, RE cycles, RE bubble JEL Classification: G21, R31, P40

Received : September 16, 2017

Revised : August 03, 2018

Accepted : August 06, 2018

1. Prince Sultan University, Prince Nasser Bin Farhan Street, Salah Ad Din, Riyadh 12435, Saudi Arabia. Email: alam.asadov@gmail.com

2. International Centre for Education in Islamic Finance (INCEIF), Lorong Universiti A, Petaling Jaya, 59100 Kuala Lumpur, Malaysia. Email: mansorhi@inceif.org

3. We would like to thank Dr. Christian Hott of Helmut-Schmidt University for sharing with us his simulation codes and Prof. Dr. Belal Baaquie of INCEIF for his valuable comments and suggestions on earlier version of this paper. 


\section{INTRODUCTION}

The global collapse of real estate (RE) markets following the 2007-2008 Subprime crisis exposes some significant flaws of conventional home financing. Among many flaws, the conventional home financing is speculative in nature and is embedded with overshooting mechanism, features that make it fragile and vulnerable to financial and economic turmoil. Many argue that the ills of the conventional system are absent in the Islamic financing alternative $e^{4}$. Unfortunately, there are not many theoretical works to back this argument in case of home financing. In this paper, we formulate two theoretical models based on the conventional housing loan and the Enhanced Musharakah Mutanaqisah ${ }^{5}$ (EMM) home financing, and compare their expected impacts on real estate prices.

Musharakah Mutanaqisah home financing is viewed as a better Islamic home financing alternative to existing Islamic financing products such as Bai' Bithaman Ajil (BBA) in Southeast Asia and Murabahah in the Middle East. However, because of its resemblance to the conventional loan in the payment structure and its benchmarking to interest rates, most of the currently applied versions of MM home financing are criticized as being an Islamic replica of the conventional mortgage. Thus, from a purely economic point of view, the effect of the contemporary MM home financings on real estate cycles should not be much different from that of the conventional housing loan.

As an alternative, we propose the Enhanced version of MM (EMM) home financing. We conjecture that, if adopted, its impact on the stability of the real estate (RE) markets and the economy should be markedly different. The main distinctive features of the proposed EMM are its use of housing rents for the calculation of the rental revenue and sharing of capital gains or losses during ownership transfer from banks to customers. We argue that, under the EMM setting, the demand for home financing will be influenced by the changes in actual economic conditions rather than interest rates determined in financial markets.

One way how the EMM home financing impacts the economy is as follows. If bank revenue from home financing is based on relatively constant housing rents, home financing is an unattractive investment for Islamic banks (IBs) at times when the price of housing appreciates. The reason is, by reducing rent-to-price ratio, the rate of return from home financing drops. Thus, during real estate booms, IBs will curtail home financing and consequently lower the demand for housing and stabilize RE markets. The opposite is expected if housing is undervalued. In such a case, home financing becomes an attractive investment because of relatively higher rent-to-price ratio. Therefore, IBs will allocate more funds for it, which will increase demand for housing and consequently correct its price upwards.

Additionally, since both parties to the EMM must share capital gain or loss of the property under transaction in line with the prescription of the Shari'ah,

4. For some examples of such arguments, one can look at the works by Hassan \& Kayed (2009), Iqbal \& Mirakhor (2011) and Chapra (2011).

5. Musharakah Mutanaqisah (MM) is a mode of Islamic financing, where bank and client enter into a contract of joint property ownership. Throughout the financing period, the client will rent banks share in the property and increase his ownership through gradual acquisition of bank's share through payment of periodic instalments. 
the financing behavior of Islamic banks using such a mode of financing will be counter-cyclical. This should contribute towards smoothening of the RE cycle. There are several reasons for such supposition. During economic boom, which usually corresponds to real estate price acceleration, Islamic banks adopting the EMM home financing would reduce home financing to avoid any future losses under suspicion of RE bubbles. As a result, it would advise its customers to delay house purchases until prices return to the normal level.

Meanwhile, in times of economic recession where the prices of the property are at the rock bottom, Islamic banks would be eager to advance financing to creditworthy customers. They would do so with hopes of making good capital gains once the housing market recovers. Even for customers who may be facing temporary problems with the payment of housing instalments during recession, banks will not urge selling off the houses. This is further encouraged by the reduction in the instalment requirements due to the declining value of the properties during recessionary periods. Those changes in the behavior of banks (and its expected influence on customers' behavior) would result in cooling down of price boom during upturns and avoidance of sharp price declines during downturn, thus resulting in the smoothening of the RE cycle ${ }^{6}$.

The above analyses suggest that the role of banks should substantially change from being an opportunistic profiteer to a sincere partner with the adoption of more Shari'ah compliant Islamic financing products ${ }^{7}$. Since Islamic banks share risk with customers and will benefit from their financial wellbeing, they will act as true partners. This partnership based on real economic factors strengthens the link between real and financial markets and reduces adverse influences of one on the other.

The main objectives of this work are twofold. First, it aims at demonstrating relatively high fluctuations in the $\mathrm{RE}$ prices under the conventional home financing. And second, it verifies the superiority of the Enhanced Musharakah Mutanaqisah (EMM) home financing over its conventional counterpart in terms of its positive impact on real estate markets. To achieve these objectives, we will set up two alternative multi-period models and rigorously analyze their impacts on real estate prices through simulations.

The rest of the paper is organized as follows. After reviewing theoretical literature on home financing in Section II, the paper formulates two alternative (Conventional and EMM based) models of home financing in Section III. In section

6. We expect tying of home financing contract to rental would make price of housing more stable since generally rental is found to be stable. In this respect Sun \& Tsang (2017) find that some rigidity in rental contracts plays an important role in explaining the smoothness of rents and relative volatility of the price-rent ratio under conventional setting.

7. By default, all Islamic finance products should be Shari'ah compliant. Otherwise, they cannot be offered by Islamic finance institutions (IFIs). However, some of Islamic finance products such as al Bai' al Inah are controversial and not accepted by the majority of Islamic schools (Madhabs). We use the phrase 'more Shari'ah compliant' for products which are free of such controversy and more in line with the 'Objectives of Shari'ah' (i.e. not only complying with the Shari'ah in form but also comply with it in substance). 
IV, the models are enhanced with the inclusion of multi-period profit maximization and are then simulated. In Section V, we draw some economic implications from the models and simulated results. Then, some suggestions for further research are provided in Section VI before the paper concludes with a general summary of the findings and some policy recommendations in VII.

\section{REVIEW OF THEORETICAL LITERATURE ON HOME FINANCING}

Large fluctuation of real estate (RE) prices and potential bubbles in the housing markets have been of great concern. Taipalus (2006) highlights three reasons why bubbles in the housing markets may be harmful to the economy. First, increasing property prices during the bubble period signals future inflation. Second, asset price escalation and its subsequent corrections bears implications on financial and banking system stability since it affects banks' valuation of loan collaterals and consequently banks' balance-sheets. Finally, asset price over-valuation may result in misallocation of resources. In most cases, this takes place because of economic agents' inability to recognize the existence of RE bubble. Due to these reasons, the damage from bursting of housing bubble could be large (Helbling \& Terrones, 2003) especially when the housing value is severely mispriced, as unfolded in many countries following the 2007-2008 Subprime Crisis.

Theoretically, in conventional finance, various studies have examined the relations between financing and asset prices. A seminal work by Kiyotaki \& Moore (1997) demonstrates the persistent effect of technological or income shocks in generating large fluctuations in the level of output and asset prices in the presence of credit limit imposed by lenders. Meanwhile, Iacoviello (2005) shows that, under nominal debt credit whose limit is tied to collateral, "... collateral effects dramatically improve the response of aggregate demand to housing price shocks; and nominal debt improves the sluggish response of output to inflation surprises" (Iacoviello, 2005, p. 739). A paper by Sommervoll, Borgersen, \& Wennemo (2010) on endogenous housing market cycles further shows that the imposition of credit constraints on mortgages may result into quite drastic collapses in house prices even if the prices are agreed by all of the economic agents.

The strong collateral effect in asset and housing markets as highlighted above is normally attributed to the 'financial accelerator' mechanism suggested by Bernanke, Gertler \& Gilchrist (1999). They claim that the procyclicality of the financial system has to do with asymmetric information about lenders and collateral values of the pledged asset. Financial accelerator posits a reinforcing effect between financing or housing markets and the business cycle. During times of economic recession when the collateral value is depressed, borrowers will have difficulty to get financing from banks irrespective of the project quality. This will further reinforce economic downturns. On the other hand, during economic booms, the value of collaterals increases and as a result, most projects will be financed and, in the process, further accelerates the economy and asset prices.

However, it is difficult to associate all large swings in house prices to the financial accelerator alone. Borio, Furfine \& Lowe (2001) argue that an additional source of financial procyclicality has to do with inappropriate reaction of financial market participants to change in risk. This is due to the difficulty in measuring 
risk or, even if risk is correctly measured, is due to egotistic incentives of some market participants. As a result, there would be socially suboptimal decisions. Such inappropriate measurement of risk, as argued in the paper, leads to its underestimation in times of boom and overestimation in times of recession. Therefore, wrong measurement of risk during booms leads to rapid credit growth, inflation in collateral value, artificially low lending spreads and shallow holding of capital provisions by financial institutions. The opposite is argued to take place during recessions. In short, there would be prolonged booms and deepened recession in the business cycles.

From the above literature, we can see many weaknesses of the conventional financial system, which have translated into recurring instability in specific asset markets as well as in the economy at large. The Islamic financial system, to the contrary, has generally been considered as a better alternative. Because of its stronger ties to the real sector, it is resilient to financial shocks and business cycles (Beck, Demirgüç-Kunt, \& Merrouche, 2013; Chapra, 2011; Hassan \& Kayed, 2009; Ibrahim, 2016; Iqbal \& Mirakhor, 2011). Even though many of Islamic products look like conventional financing products, the underlying principles on which they are based are completely different. Musharakah Mutanaqisah home financing is one such innovative product, which is based on a partnership between a financer and a purchaser of housing property. This partnership gives the two parties obligations and rights for sharing of profit or loss from rentals and changes in the value of the property during ownership transfer from the financier to the purchaser.

However, currently, many of the Islamic banks that offer Musharakah Mutanaqisah (MM) home financing link rental revenue to interest rates and employ historical value of the property during ownership transfer. Since the payment structure and benchmarking rates used in most of current applications of the MM home financing are very similar to those of conventional housing loan, it is argued that its economic impact would not be much different. Alternatively, some argue that if the practice of MM home financing is in conformity with the Shari'ah requirements of the product's underlying contacts ${ }^{8}$, both economic and social benefits would be substantially different (Abdul Razak \& Amin, 2013; Meera \& Abdul Razak, 2005, 2009; Smolo \& Hassan, 2011). Some of the requirements include the link of rental payment to an actual rental measure (such as a locational rental index) and the value of the property to be periodically revalued during ownership transfer, as is the case in the EMM home financing model proposed here.

To date, there is limited fundamental research evaluating the influences of the above propositions on banks' behavior, price of housing or the overall economy. Among early papers addressing the direct economic impact of Musharakah Mutanaqisah financing is Bendjalali \& Khan (1995). Even if their work does not

8. Underlying contacts used in Musharakah Mutanaqisah home financing are Musharakah (partnership), Ijarah (renting) and Bai' (sale). Each of those contracts have their relevant Shariah principles driving terms of agreements between parties involved. Because it is out of the scope of this paper those principles are not discussed here. However, one can refer to Zuhaili (2003) and Usmani (2007) for detailed discussion of those contracts. 
directly relate to home financing, it makes a mathematical attempt to model a standard MM product. Subsequent works addressing directly home financing, which include among others Meera \& Abdul Razak (2005, 2009), Smolo \& Hassan (2011) and Abdul Razak \& Amin (2013), do not go beyond analyses of some general issues related the MM and other Islamic home financings and/or some proposals for resolution of financing-related problems.

Theoretical works related more closely to the present study are those by Ebrahim \& Hussain (2010) and Ebrahim, Shackleton, \& Wojakowski (2011). The former suggests that the application of Participating Home financings (PMs) will increase Pareto-efficiency stemming from reduced agency costs and from sharing of risks among participants in financing. This should eventually lead to a rise in the property value. The latter work, based on different variants of PMs established in the former, argues that these PMs can improve the financial system in terms of efficiency and resiliency due to their cost efficiency and risk-sharing.

Another work which tries to link equity based home financing to stability of the RE market and the overall financial system is Mian \& Sufi (2014). They propose sharing of capital gain and loss from the value of mortgage property between the bank and the client in the form of some additional payment by the client at time of mortgage's maturity or termination and as a reduction in the amount of installment due to the bank respectively. They argue this will make both lender and borrower more thoughtful of the prices of property. However, in their proposition, Mian \& Sufi (2014) suggest that losses should be shared according to each party's contribution in the value of property, but only $5 \%$ of capital gains should go to the bank. They also totally ignore the issue of using rent instead of interest, which we have earlier argued would also make home financing unattractive for banks during boom periods.

A problem with equity based home financing alternatives such as in Ebrahim \& Hussain (2010), Ebrahim, Shackleton, \& Wojakowski (2011) and Mian \& Sufi (2014) is in their solution being only one sided. To be more specific, we can notice that the suggested PMs by Ebrahim \& Hussain (2010) and Ebrahim, Shackleton, \& Wojakowski (2011) are only limited to offering upside benefit to investors when keeping downside risk with the homeowners. Alternatively, those of Mian \& Sufi (2014) do the opposite by making investors in home financing to bear most of the downside risk while offering them only marginal upside benefits. Therefore, we can argue that such one-sided suggestions fail to bear in them the true spirit of Islamic finance, i.e. being fair and just to all parties involved in financing.

Furthermore, even if the works by Ebrahim \& Hussain (2010) and Ebrahim, Shackleton, \& Wojakowski (2011) suggest the ability of PMs in enhancing the efficiency and resiliency of the financial system, there is no mentioning of PMs' influence on real estate cycle. Also, we have not come across any study that specifically links Musharakah Mutanaqisah or PM type of home financing to real estate cycle or optimal pricing of the property. Even if resilience of Islamic banks is normally noted, there are not many theoretical papers showing how the Islamic alternative enhances the RE market efficiency or prevents the formation of RE bubbles Additionally, existing studies rarely consider impacts that true partnership arrangement under MM could have on the overall economic wellbeing. Therefore, we can conclude that there is obvious lack of theoretical 
research explaining the influence of Islamic home financing on the RE market and the economy at large.

\section{THE AGGREGATE MODELS OF HOUSING MARKET}

\subsection{General Background}

In this section, we model the conventional home financing and the Enhanced Musharakah Mutanaqisah (EMM) home financing. While the model assumptions are in general similar to those in Hott (2011), the assumptions related to rationality and market structure differ from his. Also, certain assumptions regarding profit and loss calculations under the $\mathrm{MM} \mathrm{model}^{9}$ are completely different. In our setup, there are two types of agents - households and banks - who act rationally.

Despite similarities in most assumptions, the Conventional model and the MM model differ from each other in two key aspects. First, while banks employ interest rates in the Conventional model, they use actual rental rates for the calculation of profit from home financing in the MM model. Second, while only households benefit from capital gains or bear capital losses in the former, both the banks and the households share capital gains or losses according to their shares of ownership under the MM model. Next, we will go through details of other assumptions of each model and clarify the differences as we proceed. We begin with the Conventional model and specify its assumptions, which is followed by descriptions of the MM model highlighting principally points of difference from the former.

\subsection{Conventional Model of Home Financing}

In this section, we introduce assumptions of the Conventional model in terms of real estate and home financing markets, household and banking sectors and their interactions with each other. Some assumptions are adopted from previous works on home financing while others are unique to our model specifications.

\subsubsection{Real Estate Market}

Similar to Kiyotaki \& Moore (1997), Iacoviello (2005) and Hott (2011), there are S identical homes supplied in the real estate market and the market clearing price of a home to be equal to $P_{t}$ in period $t$. Thus, $S P_{t}$ becomes the value of all homes in the economy.

Additionally, for the sake of simplification, we equate $S$ to unity $(S=1)$. We also assume that the utility from consumption and productivity in construction of housing have constant returns to scale, and therefore they are not crucial factors in the model. Those assumptions do not affect our results qualitatively, but rather are used to simplify the process of price determination in the real estate market. For

9. In this section, we are going to used 'EMM home financing' and 'the MM model' terms interchangeably since our main objective here is not to distinguish between practiced and ideal version of MM home financing. We rather intend to compare theoretical implication of the original MM home financing on real estate prices with those of the conventional mortgage. 
the conventional model, we assume that only households have ownership of the houses. However, the banks make use of the houses as collateral for housing loan in case of default by the households.

\subsubsection{Market for Home Financing}

We assume that households' demand for home financing is the only determinant of demand in the home financing market. On the supply side, banks supply home financings with a fixed maturity of $T$ period. In this model, similar to Kiyotaki \& Moore (1997) and Hott (2011), we assume that banks finance households' housing loans with fixed mortgage rate $(m)$ and get financing for themselves at a fixed finance rate $(r)$. Households make the payments of their housing loans through some fixed instalments $(I)$, which cover both interest and principal of the loans.

Another assumption which is similar to Hott (2011) is that the loan-to-value (LTV) is constant, which is assumed to be $100 \%$ for sake of simplicity. This implies that total home financings is the same as that of the new housing stock, which is $P_{t}$. This is so because we assume on average households need financing for entire housing stock they want to possess.

\subsubsection{Household Sector}

Similar to Hott (2011), we assume that the main source of households' utility comes from their use of housing and consumption of other goods. Further, we assume that the discount rate of households is very high (higher than the mortgage rate). Similar assumptions are used in other works to ensure that households' borrowing constraint is binding. This means households will accept whatever credit given for home financing. Therefore, we will be mainly concentrating on the borrowing side of home financing market while assuming that any amount of home financings offered will be accepted by households to purchase housing units.

Households use all their income for payment of housing instalments $\left(I_{t}^{i}\right)$ and for other consumptions $\left(C_{t}^{i}\right)$. In general, we assume that the number of households is $N$. In period $t$, household $i(\mathrm{i}=1, \ldots, \mathrm{N})$ buys and finances a fraction $f_{t}^{i}$ of the entire housing stock, where $\sum_{\mathrm{i}=1}^{N} f_{t}^{i}=1$. Therefore, the amount of financing from banks by household $i$ in period $t$ is $f_{t}^{i} P_{t}$ and his/her financing burden is $f_{t}^{i} I_{t}^{i}$. Additionally, in this model, we assume that all capital gains or losses from house price change go to households since banks do not own any share of the housing stock. However, households do not realize capital gains/losses until the end of the mortgage term or time of default on their instalment.

Then, a random labour income $Y_{t}^{i}$ is considered as the main source of income household $i$ receives in each period $t$. Similar to Hott (2011), we assume $Y_{t}^{i}$ to be uniformly distributed with values ranging from 0 and $\bar{Y}$, and the distribution to be independent of its historical values. Because of our assumptions about identical expected future income for all households and value for all homes, we will end up with the same borrowing constraint for all households, each owns a proportional fraction of the entire housing stock (i.e. $f_{t}^{i}=1 / \mathrm{N}$ ). Once we normalize $N$ to one (1), the budget constraint for household $i$ with regular housing loan instalment requirement of $I_{t}^{i}$ for period $t$ under the conventional model becomes: 


$$
Y_{t}^{i} \geq C_{t}^{i}+I_{t}^{i}
$$

where $C_{t}^{i} \geq 0$ is the consumption of household $i$ in period $t$. Knowing the mortgage rate $(m)$ and banks' financing rate $(r)$, we can easily calculate installment requirement $\left(I_{t}^{i}\right)$ of households for any particular year. The installment under conventional financing (assuming fixed interest rates) will be the same throughout the entire period of mortgage $\left(I^{i}\right)$ and will be calculated using the simple formula of debt amortization:

$$
I_{t}^{i}=I^{i}=\frac{m P_{0}}{1-(1+m)^{-T}}
$$

where $P_{0}$ stands for the price of the house at the start of home financing.

Assuming non-negativity of consumption, household simply defaults if its income falls short of installment requirement (i.e. Yi $<$ Ii). In the case of default, the house would be sold and the cost of financing recovered. The bank does not suffer any loss as long as selling price of the house covers remaining balance $\left(B_{t}\right)$, which is calculated using the conventional formula for each year as follows:

$$
B_{t}^{i}=B^{t}=I^{i}\left[\frac{1-(1+m)^{-(T-t)}}{m}\right]
$$

Thus, household defaults only if $Y_{t}^{i}<I^{i}$, and makes loss only if

$$
Y_{t}^{i}<I^{i}-\left(E\left(P_{t+1}\right)-B_{t}\right)
$$

Going back to our assumption of uniform distribution of household income between 0 and $Y_{t^{\prime}}$ probability of default for the bank becomes:

$$
\Omega_{t}^{d}=\frac{I}{\bar{Y}_{t}}
$$

And probability of losses becomes:

$$
\Omega_{t}^{i}=\frac{I-\left(E\left(P_{t+1}\right)-B_{t}\right)}{\bar{Y}_{t}} \text { if } 0 \leq E\left(P_{t+1}\right)-B_{t} \leq I
$$

Here we have to make sure that the probability of losses is positive and does not exceed that of default, i.e. $0 \leq \Omega_{t}^{I} \leq \Omega_{t}^{d}$. Therefore, two additional conditions also apply:

$$
\begin{aligned}
& \Omega_{t}^{I}=\Omega_{t}^{d} \text { if } E\left(P_{t+1}\right)-B_{t}<0 \\
& \Omega_{t}^{I}=0 \text { if } E\left(P_{t+1}\right)-B_{t}>1
\end{aligned}
$$

Overall, we have three possibilities for the household and bank at the end of each period:

1) Household makes full payment of instalment and continues to the next period, the probability of which is equal to $1-\Omega_{t}^{d}$.

2) Household defaults on instalment, but proceeds from home liquidation cover all of its debt and payment obligations. Probability of which is the difference between equations (5) and (6), i.e. $\Omega_{t}^{d}-\Omega_{t}{ }^{I}$ or $\frac{\left(E\left(P_{t+1}\right)-B_{t}\right)}{\bar{Y}_{t}}$ if $0 \leq E\left(P_{t+1}\right)-B_{t} \leq I$. 
3) Household defaults on instalment and proceeds from home liquidation don't cover all of its debt and payment obligations, the probability of which is equal to equation (6), (7) or (8) depending on the value of $\left(E\left(P_{t+1}\right)-B_{t}\right)$. This is the case when bank makes losses and we call it total default.

All of those three cases for the household under conventional model are illustrated in Fig. 1.

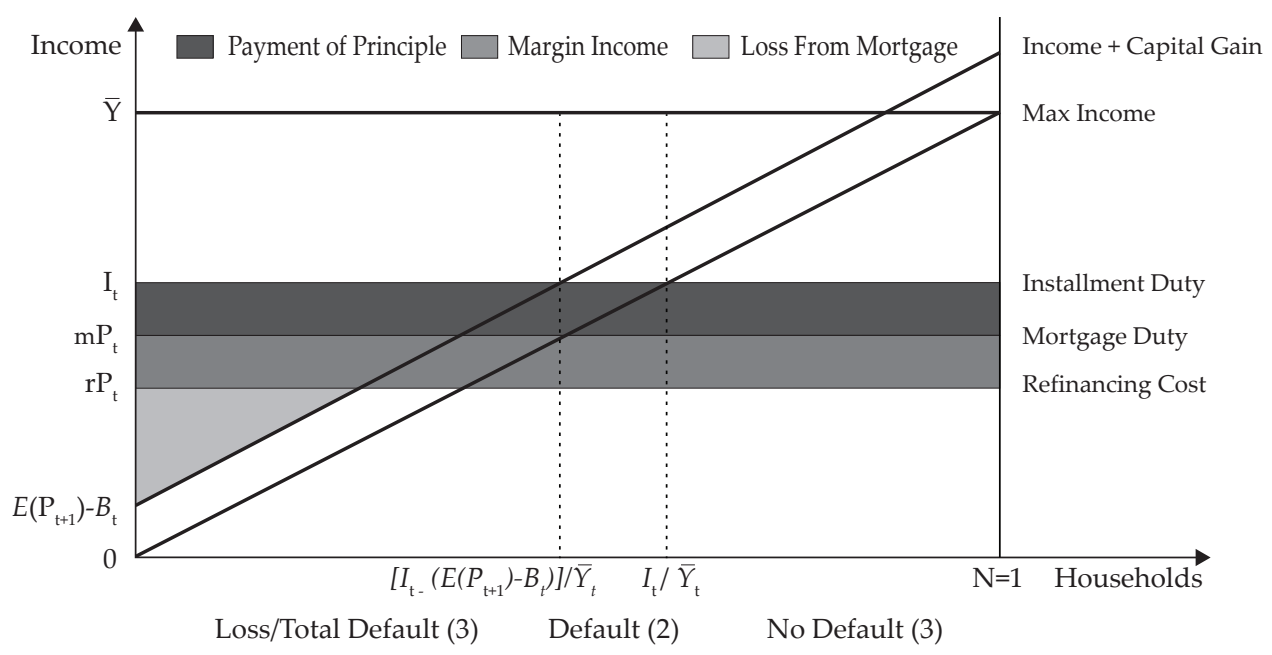

Figure 1. Banking Sector's Expected Profit or Loss from Mortgage Loan Under Conventional Model

\subsubsection{Banking Sector}

An essential element in our model is the banking sector. We adopt several assumptions from Hott (2011) for convenience and, more importantly, for comparability between the Conventional model and the MM model. Here we assume banks to be identical and risk neutral and they are not able to differentiate between different households upfront. Nevertheless, we also assume that banks are aware of each household's expected income stream and distribution and they form expectations rationally.

Additionally, we also assume that the banking sector tries to maximize its profit and banks cooperate with each other for this purpose. In this respect, the banking sector could be considered as competitive and at the same time it is able to realize some positive economic profits, unlike the assumption of zero economic profit in Hott (2011). However, similar to Hott (2011), we also assume that banks cannot make decisions about mortgage or financing rates on their own ${ }^{10}$ and only make decision about the amount of the home financings they advance. Since we assumed $N=1$ and LTV=100\%, we have both the quantity of financing and the price

10. We assume that central bank dictates those rates to the banking sector, which is not too much of abstraction from the real situation in most of the countries. 
of housing equal to $P_{t}$. Here, we assume that the mortgage rate $(m)$ is constant and positive and banks borrow at a constant financing rate $(r)$, which is between zero and $m(0<r<m)$. Thus, in period $t+1$, the banking sector's revenue from margin income will be $(m-r) P_{t}$. In addition, we will consider that banks gain or lose nothing from house price changes from one period to another $\left(P_{t+1}-P_{t}\right)$, due to the reason that the banks do not own the property. Furthermore, because of banks' inability to distinguish between "good" and "bad" households upfront, they also finance households who will default. Due to those defaults, banks' earnings reduce by the fraction $\rho_{t+1}$ of their home financing exposure. Hence, expected profits for banks is

$$
E\left(\pi_{t+1}\right)=P_{t}\left[m-r-E\left(\rho_{t+1}\right)\right]
$$

It can be considered as the difference between interest income (striped rectangle) and expected loss (grey triangle) areas in Fig. 1.

Since the banking sector does its best to maximize profit, banks would be willing to provide home financing facilities till the point where expected profit is maximized. Existence of loss from default will limit the amount of home financing, thus the price of housing $\left(P_{t}\right)$. The increase in price moves up the instalment $\left(I_{t}\right)$, the mortgage duty $\left(m P_{t}\right)$ and the financing costs $\left(r P_{t}\right)$ lines, while also increases the revenue from interest spread. However, given that the expected real estate price in period $t+1$ is unchanged, the households' expected capital gains decline and the "Income + Capital gain" line in Fig. 1 is pushed downwards. Both of those effects do not have impact on the interest margin $(m-r)$, except for reducing the expected capital gains for the households $\left(E\left(P_{t+1}\right)-P_{t}\right)$ and increasing the expected rate of losses $\left(r_{t+1}\right)$. Therefore, banks set the quantity of home financing at point where the expected profit is maximized:

$$
\operatorname{Max}_{P t} E\left(\pi_{\mathrm{t}+1}\right)=P_{t}\left[m-r-E\left(\rho_{t+1}\right)\right]
$$

Overall, the banking sector has control over home financing $\left(P_{t}\right)$. Accordingly, banks provide the optimal level of financing which maximizes their profit.

\subsection{Musharakah Mutanaqisah (MM) Model of Home Financing}

In this section, we develop the theoretical structure of the Enhanced Musharakah Mutanaqisah (EMM) home financing model. There are some other proposals of the MM home financing with similar specifications such as those by Meera \& Abdul Razak (2005, 2009) and Abdul Razak \& Amin (2013). However, those works do not analyze theoretically the impacts that the MM home financing will have on the real estate market or the economy at large.

Meanwhile, analyzing the theoretical impacts of Participating Home financings (PMs) on the financial system, Ebrahim \& Hussain (2010) and Ebrahim, Shackleton, \& Wojakowski (2011) propose home financing models substantially different from the MM home financing model proposed here. Even if the Shared Equity Home financings (SEMs) version of the PMs proposed by them is similar to the EMM model to some degree, some of our hypotheses run counter to the findings of the above-mentioned works. That difference could be due to some discrepancies in 
model assumptions and approaches to the problem ${ }^{11}$. For instance, one difference is in the profit and loss sharing assumption, which is adopted in its entirely in the EMM model but adopted partially in all variants of PMs.

Therefore, it can be argued that the model and approach used in this paper is quite different from the ones used in other works on Islamic home financing. The detailed features of the EMM model will be explained together with descriptions of its assumptions.

\subsubsection{Real Estate and Home Financing Markets}

Most of the assumptions regarding the real estate market aspect of the Enhanced Musharakah Mutanaqisah home financing model (MM model afterwards) are similar to those of the Conventional model. The main difference between the Conventional and MM models relates to the assumption of ownership. In contrast to the Conventional model, the MM model assumes joint ownership of the property between banks and households with their respective shares corresponding to their investment in the property. On the basis of the Musharakah (partnership) principle of the MM, all involved parties should share the profits according to mutually agreed ratios and losses according to their shares of ownership in the property.

The modus operandi of the MM home financing is as follows. It starts with banks buying houses in partnership with households and the former sell off their shares in the houses to the latter throughout home financing period of $T$. We assume this process takes place smoothly throughout the entire home financing period and banks own share of the new housing stock according to the proportion of their financing while households own the rest. Unlike in the Conventional model, we assume that households pay to the banks a portion of fixed rental $(M)$ and banks finance their home financing with fixed financing payment $(R)$ according to their share in ownership.

\subsubsection{Household Sector}

Besides the general assumptions of household sector as in the Conventional model, assumptions regarding household sector under the MM model are different in terms of financing and default probabilities. Here, we assume that households use their entire income for paying their house rental to banks $\left(b_{t-1}^{i} M\right)$, buying out some shares of the house $\left(s_{t}^{i} P_{t-1}\right)$ and for consumption purposes $\left(C_{t}^{i}\right)$. At year $t$ household $i$ will own certain share of the house equal to $h_{t}^{i}=\sum_{x=0}^{\mathrm{t}} S_{t-x}^{i}$, and share

11. Some clear differences are in product features, approaches and results. First, as mentioned earlier in Introduction, while SEMs only capture upside potential of earnings and price gains from home ownership, the EMM covers both upside gains and downside risk of property ownership. Next, this work approaches the issue from more macro perspectives while the above-mentioned works use more micro perspectives. Finally, our results in Section 4 suggest that in general prices of the properly will decrease with the adoption of the EMM model, while the results from Ebrahim \& Hussain (2010) suggest that the property prices would increase if the PMs are adopted. 
owned in the beginning of financing is equal to $h_{t_{0}}^{i}$ where $t_{0}$ refers to beginning period. Thus, the rental burden of household $i$ in period $t$ is: $\left(1-h_{t-1}^{i}\right) M$.

Additionally, in the MM model, the households have income from capital gains in proportion to their ownership shares $\left(h_{t}^{i}\right)$. However, they do not realize capital gains until the end of the mortgage term or when they default due to the inability to make the required payment to the banks. The following budget constraint under the MM model for household $i$ in period $t$ with regular acquisition of $s_{t}^{i}$ share of the house from banks:

$$
Y_{t}^{i} \geq C_{t}^{i}+b_{t-1}^{i} M+s_{t}^{i} P_{t-1}
$$

where $C_{t}^{i} \geq 0$ is the consumption of household $i$ in period $t, b_{t-1}^{i}=\left(1-h_{t-1}^{i}\right)$ is the bank $i^{\prime}$ s ownership share in the house at period $t-1$ and $s_{t}^{i} P_{t-1}$ is the required payment for share acquisition by household $i$ in period $t$. Since consumption cannot be negative, household $i$ defaults if $Y_{t}^{i}<b_{t-1}^{i} M+s_{t}^{i} P_{t-1}$. Because income is uniformly distributed over 0 to $\bar{Y}_{t}$ in period $t$, the probability of a household's defaulting on rental payment and acquisition of $s_{t}{ }^{i}$ share of the house is:

$$
\Omega_{t}^{a}=\frac{b_{t-1}^{i} M+s_{t}^{i} P_{t-1}}{\bar{Y}_{t}}
$$

However, failure to aquire the specified share from the banks does not mean total default. According to the MM agreement, households can't be forced to acquire the house from the banks and thus they are only considered defaulting if they fail to pay rent $\left(b_{t-1}^{i} M\right)$. Assuming that households only pays rents, the new budget contstraint for those households would be:

$$
Y_{t}^{i} \geq C_{t}^{i}+b_{t-1}^{i} M
$$

Since household does not acquire the share of the house from the banks, it does not have to pay $s_{t}^{i} P_{t-1}$ to the banks (so this fraction is missing from the right hand side of the inequality and it is the main difference of equation ( $\left.3^{\prime}\right)$ from (2'). Again, assuming that consumption cannot be negative household $i$ defaults only if $Y_{t}^{i}<b_{t-1}^{i} M$. Thus, in period $t$ the probability that a household will default is:

$$
\Omega_{t}^{b}=\frac{b_{t-1}^{i} M}{\bar{Y}}
$$

Overall, we have three possibilities for households:

1) Households pay full rent and acquire the share that they is supposed to acquire from the banks for the given year $\left(s_{t}^{i} P_{t-1}\right)$, the probability of which is $1-\Omega_{t}^{a}$.

2) Households pay full rent but acquire none or only a part of the share that they are supposed to acquire from the banks for a given year, The probability of which is the difference between ( $\left.2^{\prime}\right)$ and (4), $\Omega_{t}^{a}-\Omega_{t}^{b}$ or $s_{t}^{i} P_{t-1} / \bar{Y}_{t}$.

3) Households fail to pay even full rent and of course acquire none of the share that they are supposed to acquire from the banks for the given year, the probability of which is equal to (4'). This is the total default case. However, if we generalize the case for all households, equations (5') and (6 ') below will replace (2') and (4') respectively. 


$$
\begin{aligned}
& \Omega_{t}^{a}=\frac{b_{t-1} M+s_{t} P_{t-1}}{\bar{Y}} \\
& \Omega_{t}^{b}=\frac{b_{t-1} M}{\bar{Y}}
\end{aligned}
$$

The graphical representation of all three cases for the households is shown in Figure 2 below:

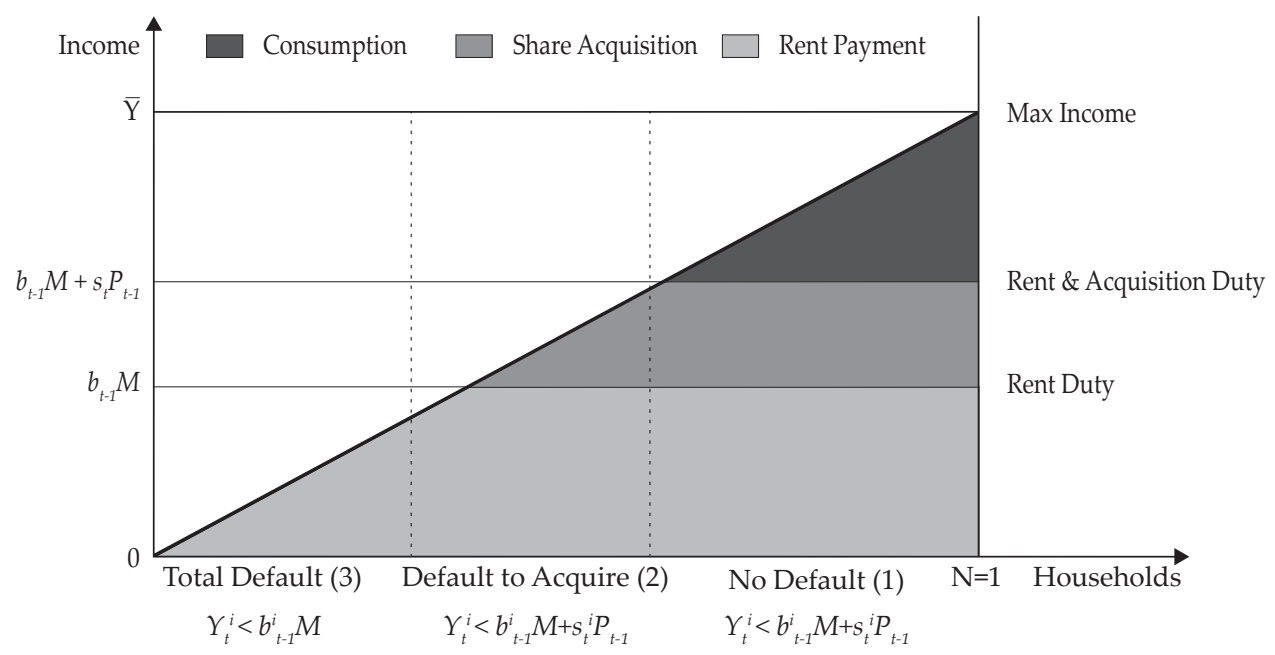

Figure 2. Households' Income, Consumption, Rental \& Acquisition Duties and Defaults Under MM model

\subsubsection{Banking sector}

In the MM model, contrary to Hott (2011), we will introduce some distinct assumptions. The assumptions which we have not mentioned in this part should be considered similar to the ones we have made for the Conventional model. Here we assume that banks provide home financings under the Musharakah Mutanaqisah principles to households for a constant amount of rental $(M)$ while financing themselves with constant financing amount $(R)$. The portion of rental received and financing paid depend on bank's latest share of ownership in the house, i.e. $b_{t-1} M$ and $b_{t-1} R$ repectively. Accordingly, the expected profit can be written as equation $\left(7^{\prime}\right)$ below, which can be shown as the difference between striped and grey areas in Fig 3.

$$
E\left(\pi_{t+1}\right)=b_{t}\left[M-R-E\left(\rho_{t+1}\right) P_{t}\right]+s_{t+1}\left[E\left(P_{t+1}\right)-P_{t}\right]
$$

The implications of those assumptions are such that both the rental amount and the financing cost are independent of the house price (i.e. the home financing). Like the Conventional model, banks provide the amount of home financing that maximizes their profit: 


$$
\operatorname{Max}_{P t} E\left(\pi_{t+1}\right)=b_{t}\left[M-R-E\left(\rho_{t+1}\right) P_{t}\right]+s_{t+1}\left[E\left(P_{t+1}\right)-P_{t}\right]
$$

Here also, like the Conventional model, the banks provide the optimal level of financing till the point of profit maximisation. However, the optimal points may not be the same in those two models since their objective functions and constraints are different.

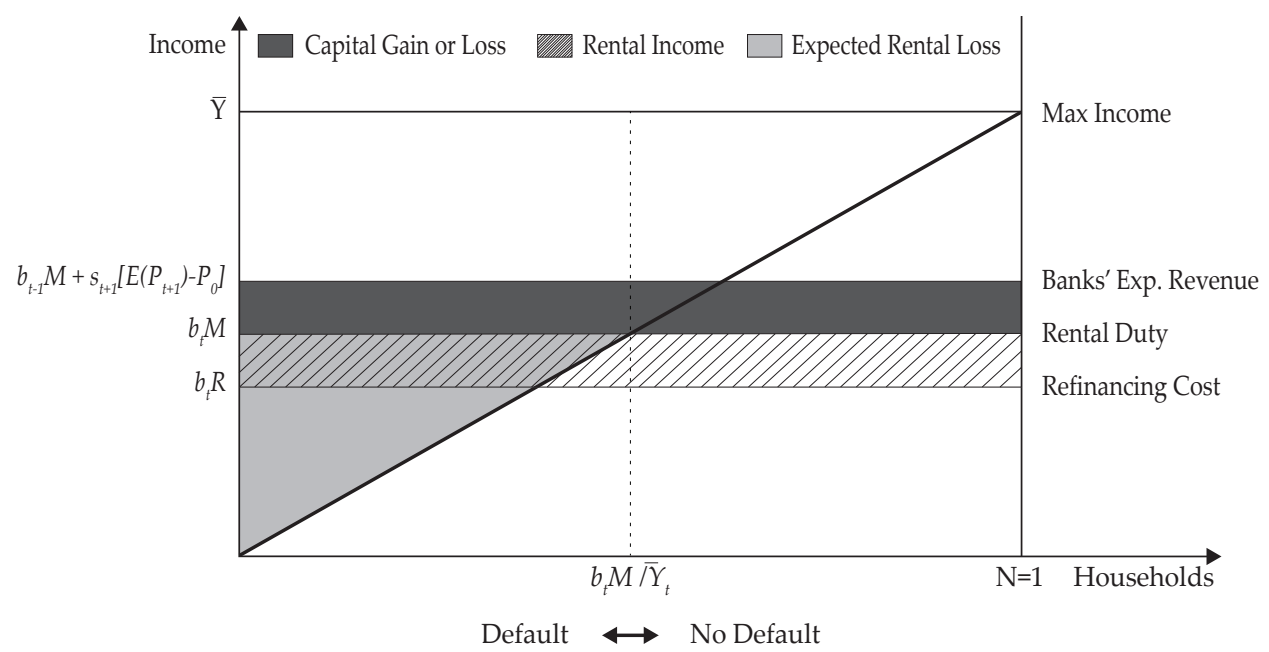

Figure 3. Banks' Expected Capital Gain or Loss, Rental Margin \& Expected Loss from Rental Under MM Model

\section{MULTI-PERIOD MODELS OF HOME FINANCING}

Even though we have mentioned that homes are financed for more than one $(T)$ period in the earlier section, we have not discussed banks' multi-period objective functions or assumptions regarding income and house prices. In this section, we will further develop our two models (i.e. Conventional and MM models). Following are additional assumptions, which are applicable to the Conventional model or the MM model or both.

For both models, rather than assuming households get financing for only one period we assume that households get financing for the entire period of home financing $(T)$.

i. We assume that banks have rational expectations about the future maximum income for households $\left(E_{t}\left(\bar{Y}_{t+n}\right)\right)$ as well as the future price of the houses $\left(E_{t}\left(P_{+n}\right)\right)$, which are specified by the following equations:

$$
\begin{aligned}
& \left(E_{t}\left(\bar{Y}_{t+n}\right)=E_{t}\left(\bar{Y}_{t+n} \mid \bar{Y}_{t-1}, \bar{Y}_{t-2}, \ldots \bar{Y}_{t-T}\right)\right. \\
& \left(E_{t}\left(P_{t+n}\right)=E_{t}\left(P_{t+n} \mid P_{t-1}, P_{t-2}, \ldots P_{t-T}\right)\right.
\end{aligned}
$$

ii. Household income is assumed to move in a cyclical fashion according to the mean income over the years with the cycle reoccurring in constant intervals. 
While households take the price risk in conventional mortgage financing, both banks and households share the risk according to their respective shares of ownership in the MM home financing. For the calculation of banks' home financing revenues and costs, we use fixed mortgage and financing rates for conventional financing and the fixed rental and financing amounts for MM financing.

\subsection{Conventional model of multi-period profit maximization}

We begin the model by first defining components of banks' profit function. Total revenue is the financing margin obtained by the banks (i.e. $B_{t-1}(m-r)$ ), total loss is the probability of loss times incurred loss (i.e. $\left.\left[I-\left(E\left(P_{t+1}\right)-B_{t+1}\right)\right]^{2} / 2 \bar{Y}_{t}\right)^{12}$. Finally, the net profit equals gross profit less total loss times continued financing. Continued financing is the fraction of borrowers who have not defaulted on their installment obligation (i.e. $1-\Omega_{t}{ }^{d}=1-I / \bar{Y}_{t}$ ). Therefore, the expected net profit of banks for a given year $t$ is:

$$
E\left(\pi_{t}\right)=\left[\beta_{t}(m-r)-\frac{\left[I-\left(E\left(P_{t+1}\right)-B_{t+1}\right)\right]^{2}}{2 \bar{Y}_{t}}\right] F_{t}
$$

where $F_{t}=F_{t-1}\left(1-I_{t} / \bar{Y}_{t}\right)$ and $F_{0}=1$

Here $F_{t}$ represents the fraction of the original households who continue with home financing.

The objective of the banks would be to maximize the net present value (NPV) of expected net profits throughout the life of the mortgage, subject to all the given constraints. Therefore, we will have following objective function:

$$
\operatorname{Max}_{P_{0}} E(\Pi)=\Sigma_{t=1}^{T} \frac{E\left(\pi_{t}\right)}{(1+m)^{t}}
$$

To calculate the net present value (NPV) of expected net profits we are using mortgage rate mainly because it is the opportunity cost of funds for the banks. Here, the banks will set optimal amount of financing and thus the housing price at period $t=0$ (i.e. $P_{0}$ ) to maximize the NPV of all future profits.

\subsection{Musharakah Mutanaqisah (MM) Model of Multi-Period Profit Maximization Assumptions will be somewhat different in the case of the MM model. First, as mentioned in Section 3.2, banks provide home financing for constant rental amount $(M)$ and finance it with fixed financing payment $(R)$. We assume those rates do not change throughout home financing period. This is based on two assumptions - there is no inflation and the average income stays the same even if it fluctuates around its mean. Since the rent is more stable than income or price of housing, we assume it to be constant. The same goes with financing cost of banks since it is derivative of rental ${ }^{13}$.}

12. The total loss can be calculated by using the area of loss depicted in Fig. 3.

13. We will relax this assumption of fixed rental and financing amounts in one of the simulations of the MM model and let them to fluctuate along the household income. As can be seen in the next section the relaxation of this assumption does not change simulation outcomes of the MM model significantly. 
Here, we assume that households default if they fail to pay installment requirement $\left(I_{t}\right)$ for that year ${ }^{14}$. But installments will be determined differently in the case of the MM model and they vary year by year depending on the market price of the house. The installment in year $t$ is calculated using the following formula:

$$
I_{t}=\frac{b_{t-1} P_{t-1} m_{t-1}}{1-\left(1+m_{t-1}\right)^{-(T-t+1)}}
$$

Where $b_{t-1}$ stands for the fraction of the house owned by the bank at period $t-1$ and $m_{t-1}$ stands for rate of discounting used by the bank, which depends on house price and rent $b_{t}$ and $m_{t}$ are calculated as follows:

$$
\begin{aligned}
& b_{t}=\frac{b_{t-1} P_{t-1}-\left(I_{t}-b_{t-1} P_{t-1} m_{t-1}\right)}{P_{t-1}}=\frac{b_{t-1} P_{t-1}\left(1+m_{t-1}\right)-I_{t}}{P_{t-1}} \\
& m_{t}=\frac{M_{t}}{P_{t}}
\end{aligned}
$$

Once (12') is known we can easily calculate the fraction owned by the household $h_{t}$ as $h_{t}=1-b_{t}$. Similar to conventional case, household simply defaults if its income is less than installment requirement (i.e. $Y_{t}^{i}<I_{t}$ ). In this case, the house would be liquidated and its price would be shared between the household and the bank according to their ownership shares. Bank does not suffer any loss of revenue as long as household's fraction in the property along with its income covers installment for that period. Thus, household defaults only if $Y_{t}^{i}<I_{t}$, and loss in revenue only occurs if

$$
Y_{t}^{i}<I_{t}-h_{t+1} E\left(P_{t+1}\right)
$$

Given the assumption of uniform distribution of household income between 0 and $\bar{Y}_{t^{\prime}}$ the probability of default for the household becomes:

$$
\Omega_{t}^{d}=\frac{I_{t}}{\bar{Y}_{t}}
$$

And the probability of loss is:

$$
\Omega_{t}^{I}=\frac{I_{t}-h_{t+1} E\left(P_{t+1}\right)}{\bar{Y}_{t}} \text { if } I_{t}-h_{t+1} E\left(P_{t+1}\right) \geq 0
$$

Since it shares capital gain or loss per its share of ownership, the bank also exposes to the price risk in addition the loss in revenue. Therefore, there are two

14. As was mentioned earlier if we stick to true principles of Musharakah, household cannot be considered defaulting on its obligation as long as it is paying rental portion of the installment. In other words, there is no real obligation for household to acquire certain amount of bank's share at a particular period of time. However, to make our analysis comparable to conventional home financing we consider household to be defaulting once it fails to pay the installment. Currently, this practice is also considered as a norm even with Islamic banks. 
additional sources of profit or loss from the changes in house price. The first source is from yearly exposure resulting from the transfer of shares through part of installments. Here, the bank can gain if the current price is higher than the initial price at the time of financing. The second source is the price risk exposure at the time of premature liquidation either because of default or early settlement. Here, the exposure captures the entire share of the house owned by the bank. Those two exposures give us the Total Exposure $\left(T E_{t}\right)$, which have both downside and upside risks, and its expected value could be represented as follows:

$$
E\left(T E_{t}\right)=\left(b_{t}-b_{t+1}\right)\left(P_{t}-P_{0}\right)-\frac{I_{t}}{\bar{Y}_{t}}\left[b_{t+1}\left(E\left(P_{t+1}\right)-P_{0}\right)\right]
$$

Putting all those considerations together, the expected net profit of the bank under MM model for a given year $t$ is written as follows:

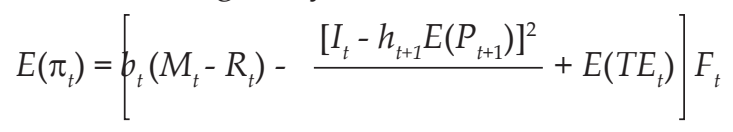

As defined in the conventional model, $F_{t}$ represents the fraction of original households with financing in the previous period and continue with the financing this period. In the MM case, the objective of the bank would be similar, which is to maximize the net present value (NPV) of expected net profits throughout the life of the mortgage, subject to all of the given constraints. Therefore, we will have the following objective function:

$$
\operatorname{Max}_{P_{0}} E(\Pi)=\Sigma_{t=1}^{T} \frac{E\left(\pi_{t}\right)}{\left(1+m_{0}\right)^{t}}
$$

Note that we use the initial profit rate $\left(m_{0}\right)$ to calculate the NPV of the expected net profits. The reason for this is that the opportunity cost of funds for the bank at the initial stage is equal to that rate of return.

\subsection{Simulation results}

Having defined each model, we proceed to simulation of the models and compare the simulation results of the Conventional and MM models. We set the mean of the maximum income $\left(\bar{Y}_{t}\right)$ to be equal to 10 and its fluctuation to be 0.5 or $5 \%$ of the mean value. The fluctuation of income is represented by the sine function with the full cycle completing in 20 periods (years). The bank also expects future house prices to fluctuate in a similar fashion with their values fluctuating by $5 \%$ of the average $^{15}$. For the conventional case, we set the mortgage rate to $5 \%$ and bank financing rate to $2.5 \%$.

As for the MM case, we use fixed rental amount and financing cost (which are equated to mortgage and financing paid for the average amount of home financing

15. We are aware that usual shape of both business cycle and real estate cycle has longer phase of growth and relatively shorter decline phase. However, the results should not be significantly different even if we use symmetric cycles represented by sine function. In another note, our assumption about full RE cycle completing in 20 years is in line with findings of the most papers, which found it to be between 15-20 years. 
under the conventional case). Later, we relax this assumption and allow them to fluctuate in the same manner as income. We set the total period of mortgage $(T)$ to be 30 years and consideration of default or continuation decision to be done annually. Simulations are conducted for 21 periods (years) just to make sure that both the RE and business cycles are completed in full. The results obtained from the simulation of the Conventional and MM models are presented below in tables 1 and 2 respectively.

Table 1.

Descriptive Statistics of Simulation Results for Conventional Model

\begin{tabular}{|c|c|c|c|c|c|c|}
\hline Parameter & $\begin{array}{c}\text { Max } \\
\text { Income } \\
\left(\bar{Y}_{t}\right)\end{array}$ & $\begin{array}{c}\text { Price of } \\
\text { Housing } \\
\quad\left(P_{t}\right)\end{array}$ & $\begin{array}{l}\text { NPV of E. } \\
\text { Profit } \\
\text { (प) }\end{array}$ & $\begin{array}{c}\text { Installment } \\
\text { Requirement } \\
\qquad\left(I_{t}\right)\end{array}$ & $\begin{array}{l}\text { Max. } \\
\text { Cons. } \\
\left(\bar{Y}_{t}-I_{t}\right)\end{array}$ & $\begin{array}{c}1^{\text {st }} \text { Year } \\
\text { Defaults } \\
\left(\Omega_{1}^{d}\right)\end{array}$ \\
\hline Mean & 10.000 & 45.420 & 2.782 & 2.955 & 7.045 & 0.295 \\
\hline S.D. & 0.363 & 13.160 & 0.327 & 0.856 & 0.959 & 0.084 \\
\hline C.V.* & 0.036 & 0.290 & 0.117 & 0.290 & 0.136 & 0.283 \\
\hline Min & 9.500 & 28.556 & 2.316 & 1.858 & 5.722 & 0.186 \\
\hline Max & 10.500 & 64.650 & 3.208 & 4.206 & 8.390 & 0.414 \\
\hline
\end{tabular}

*C.V. stands for coefficient of variation, which is ratio of a variable's standard deviation to its mean.

From tables 1 and 2, we can observe some interesting differences. The mean as well as the standard deviation and coefficient of variation (i.e. fluctuation) of house prices seem to be much lower under the MM setting than the Conventional setting. This difference is further depicted in Figure 4. In addition, the expected profit under the MM setting is higher and less volatile (See Fig. 5). We may also observe that the required installment and its variation are also lower when the MM models is used (See Fig. 6). This in fact translates into higher and smoother consumption of other goods. The overall results seem to be supportive of our profit and loss sharing oriented financing (under MM model). It leads banks to be less aggressive in terms of advancing home financing, as manifested by lower and more stable prices under the MM setting as presented in figures 4 and 7 .

Table 2.

Descriptive Statistics of Simulation Results EMM Model

\begin{tabular}{|c|c|c|c|c|c|c|}
\hline Parameter & $\begin{array}{c}\text { Max } \\
\text { Income } \\
\left(\bar{Y}_{t}\right)\end{array}$ & $\begin{array}{c}\text { Price of } \\
\text { Housing } \\
\quad\left(P_{t}\right)\end{array}$ & $\begin{array}{l}\text { NPV of E. } \\
\text { Profit } \\
\text { (ळ) }\end{array}$ & $\begin{array}{c}\text { Installment } \\
\text { Requirement } \\
\left(I_{t}\right)\end{array}$ & $\begin{array}{l}\text { Max. } \\
\text { Cons. } \\
\left(\bar{Y}_{t}-I_{t}\right)\end{array}$ & $\begin{array}{c}1^{\text {st }} \text { Year } \\
\text { Defaults } \\
\left(\Omega_{1}^{d}\right)\end{array}$ \\
\hline Mean & 10.000 & 19.511 & 4.437 & 2.362 & 7.638 & 0.237 \\
\hline S.D. & 0.363 & 2.768 & 0.362 & 0.041 & 0.389 & 0.011 \\
\hline C.V.* & 0.036 & 0.142 & 0.082 & 0.017 & 0.051 & 0.045 \\
\hline Min & 9.500 & 16.059 & 3.968 & 2.315 & 7.105 & 0.222 \\
\hline Max & 10.500 & 23.716 & 4.966 & 2.427 & 8.173 & 0.251 \\
\hline
\end{tabular}

${ }^{*} \mathrm{C}$.V. stands for coefficient of variation, which is ratio of a variable's standard deviation to its mean. 


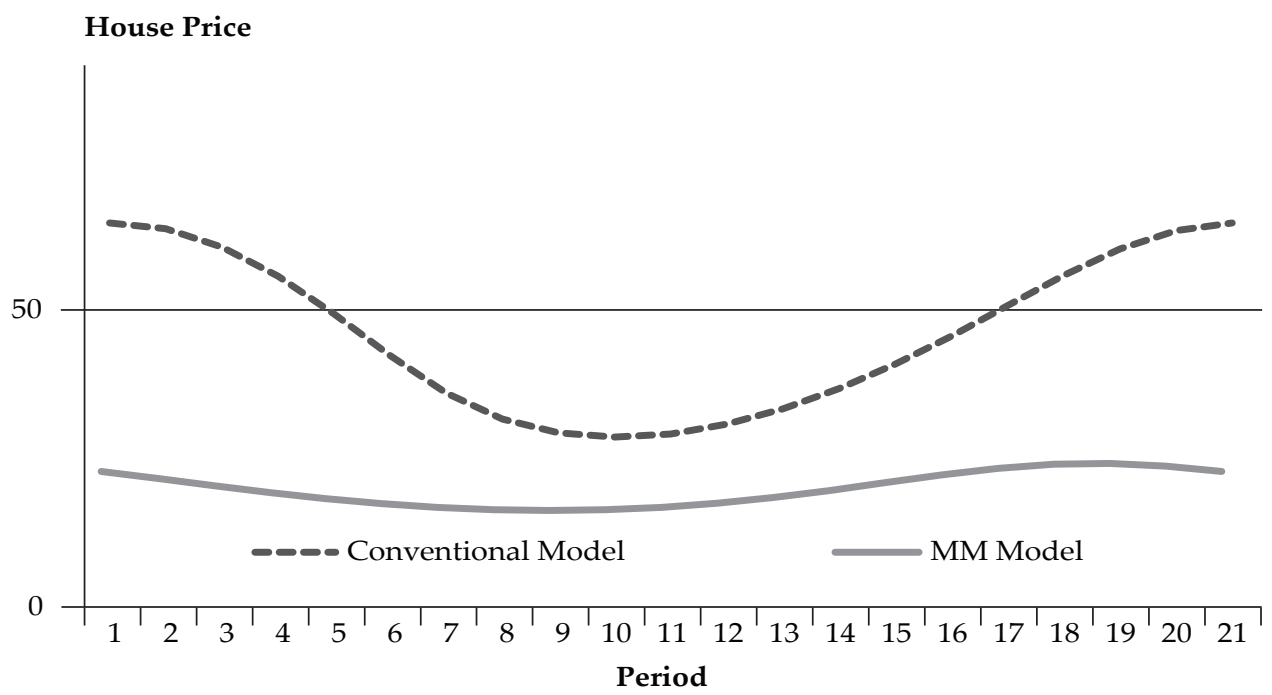

Figure 4 .

Comparison of Housing Price Under Conventional and MM Settings

A comparison of normalized values (around 1.00) of the household income and house prices, as given in Figure 7, further insights on the relative fluctuation of each variable and on the co-movement of prices (i.e. financing) and income under the two models.

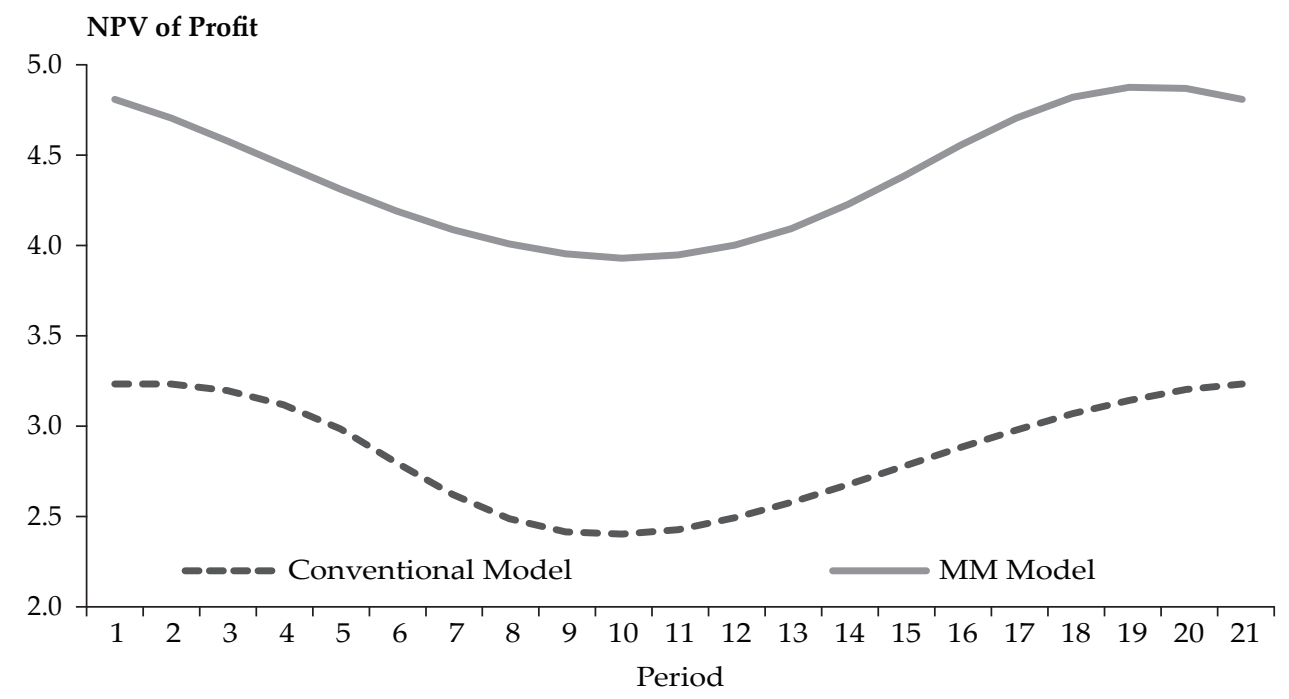

Figure 5. Comparison of banking sector's expected profit under Conventional and MM settings 
In terms of fluctuation we know that income is assumed to fluctuate within $5 \%$ range around the mean. Furthermore, when we compare relative fluctuation of prices under Conventional and MM settings we can observe the huge differences.

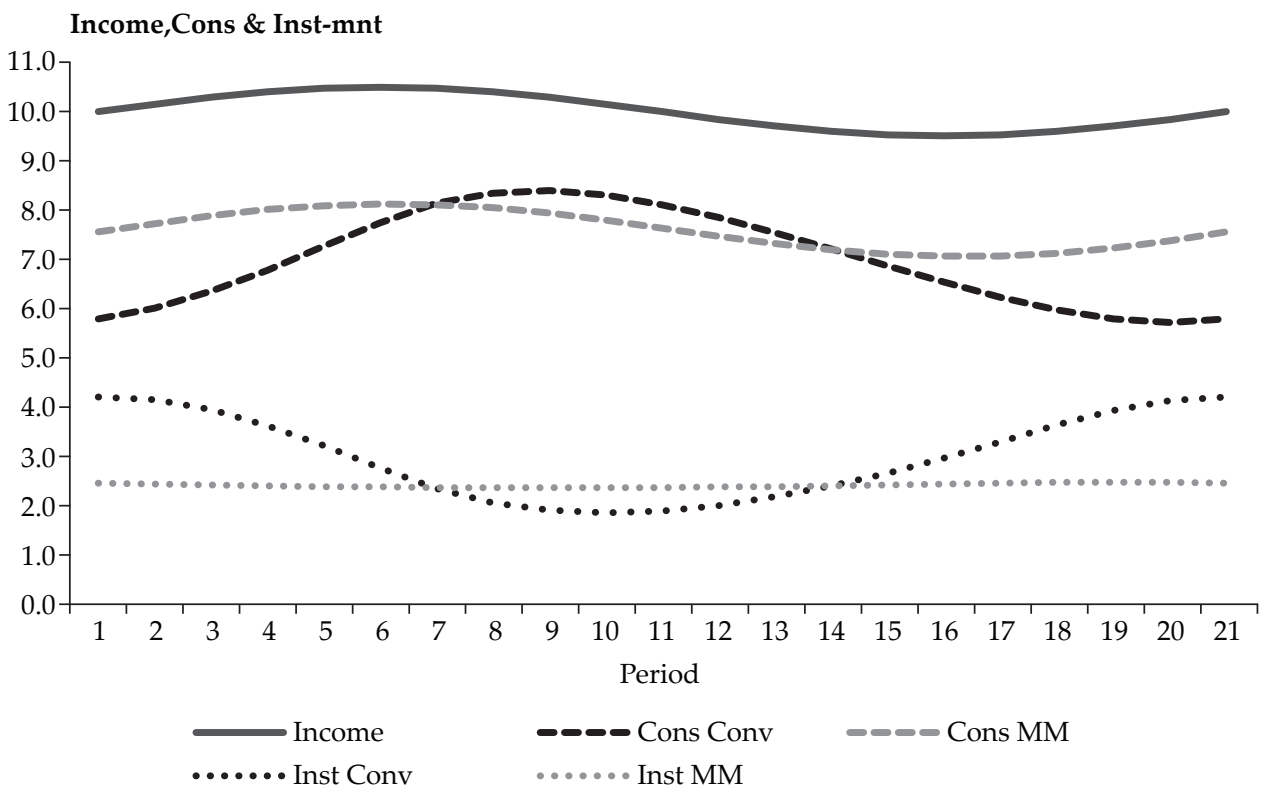

Figure 6. Comparison of Max. Income and Consumptions, and Installment Requirement of HHs Under Conventional and MM Settings

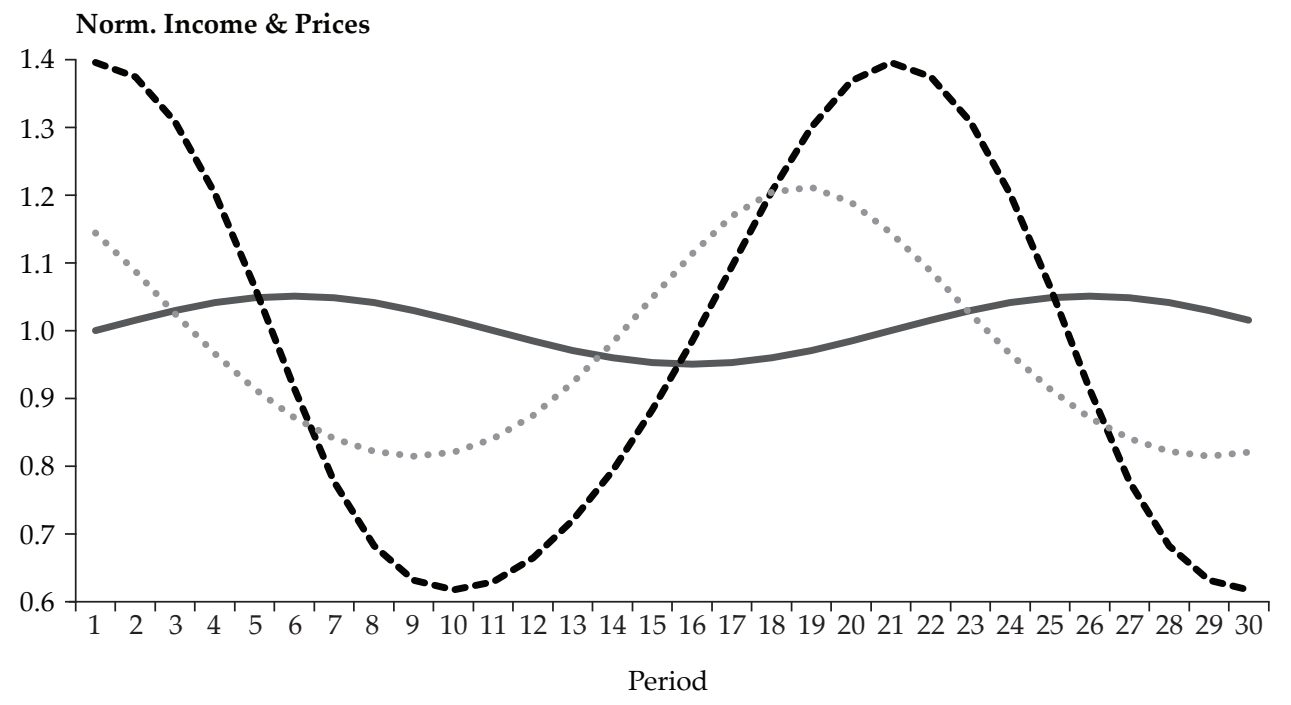

- Income - - - Price - Conv. Model ….... Price - MM Model

Figure 7. Comparison of Normalized Income and House Prices Under Conventional and MM Settings 


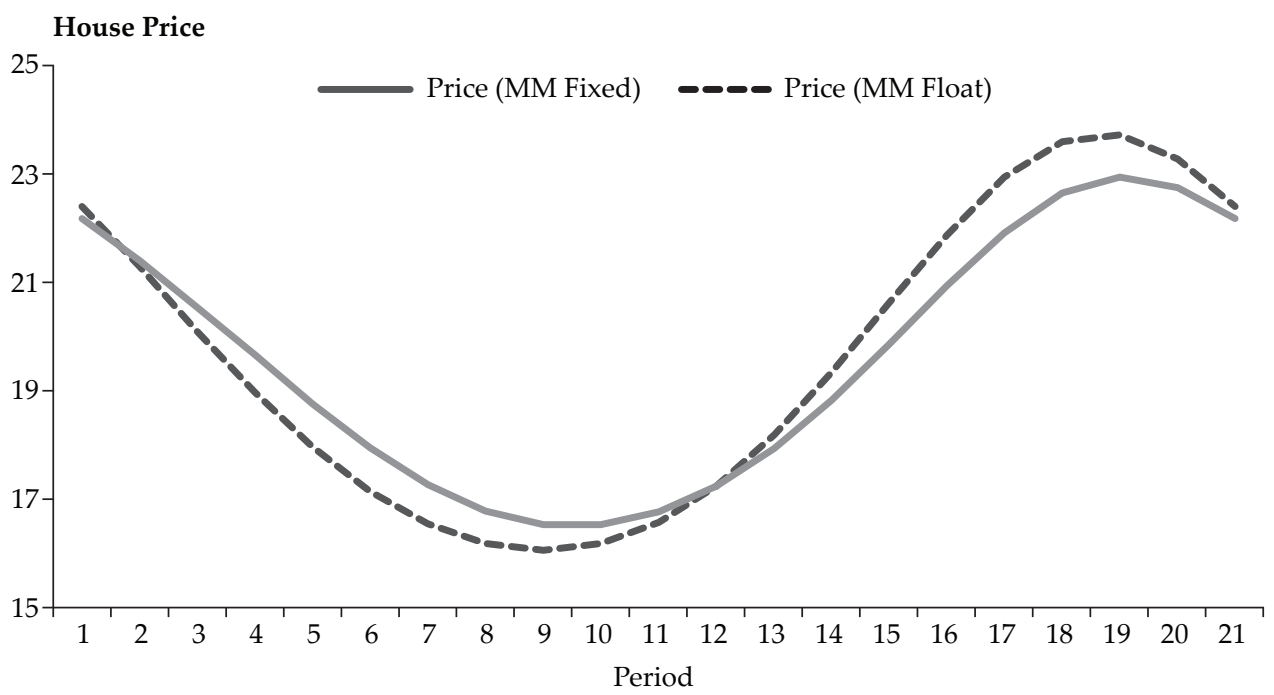

Figure 8. Comparison of House Prices Under MM Models with Fixed and Floating Rental and Financing Costs

Table 3.

Comparison of Descriptive Statistics of Simulation Results for Musharakah Mutanaqisah Model with Fixed and Floating Rental and Financing costs

\begin{tabular}{lrrrrrr}
\hline & $\begin{array}{c}\text { Parameter } \\
\text { Price of } \\
\text { Housing } \\
\text { Statistics }\end{array}$ & $\begin{array}{c}\text { Price of } \\
\text { housing } \\
\text { (MM float) }\end{array}$ & $\begin{array}{c}\text { Installment } \\
\text { requirement) } \\
\text { (MM fixed) }\end{array}$ & $\begin{array}{c}\text { Installment } \\
\text { requirement } \\
\text { (MM float) }\end{array}$ & $\begin{array}{c}1^{\text {st }} \text { year } \\
\text { default rate } \\
\text { (MM fixed) }\end{array}$ & $\begin{array}{c}1^{\text {st }} \text { year } \\
\text { default rate } \\
\text { (MM float) }\end{array}$ \\
Mean & 19.511 & 19.473 & 2.362 & 2.361 & 0.237 & 0.236 \\
S.D. & 2.768 & 2.299 & 0.041 & 0.066 & 0.011 & 0.002 \\
C.V.* & 0.142 & 0.118 & 0.017 & 0.028 & 0.045 & 0.010 \\
Min & 16.059 & 16.532 & 2.315 & 2.264 & 0.222 & 0.233 \\
Max & 23.716 & 22.938 & 2.427 & 2.447 & 0.251 & 0.240 \\
\hline
\end{tabular}

While the fluctuation of House prices (and therefore home financing) under the MM model is approximately within $20 \%$ of the mean value, it is about twice the size (i.e. within $40 \%$ of the mean value) under the conventional setting. When it comes to the cyclical behavior of house prices, it is easily observable that the house prices (i.e. home financing by banks) under the MM setting tend to be more counter-cyclical than those under the Conventional setting.

Finally, even if we relax the assumption of the fixed rental and financing cost under the MM setting, the results pertaining to house prices, installment requirement and other parameters are not significantly different from the earlier results. In fact, as can be observed from Table 3 and Fig. 8, house prices become even more smoother around the same price range. Therefore, we can safely conclude that irrespective of the assumptions about rental and financing costs, we will be getting better results under the MM setting. This simulated evidence is 
taken as a proof of our hypothesis that the enhanced MM Islamic home financing has a better ability in smoothing the RE cycle. Furthermore, the counter-cyclicality of the MM model means that it can act as an automatic stabilizer.

\section{ANALYSIS OF RESULTS AND ECONOMIC IMPLICATIONS}

The simulation results presented in Section 4.3 serve as an unambiguous evidence for the superiority of the Islamic home financing over the conventional housing loan. Some of such advantages are its contribution towards the reduction of house price inflation, smoothening of the real estate cycle and home financing countercyclicality. Some other expected benefits are less problem of adverse selection at time of advancing housing loans and other benefits to economy from adoption of the EMM home financing.

\subsection{Benefits to the Economy}

As can be observed in many countries, the pro-cyclical behavior of real estate (RE) prices characterized by the formation of RE bubbles during the expansion phase and bursting of the bubbles during the contraction phase have had disastrous real consequences. One reason for the formation of the RE bubbles is easy access to housing loans during times of economic boom. We suspect (as many others) that opportunistic behavior of conventional banks drives them to advance housing loans to many (and sometimes underqualified) home-buyers at times of economic boom, even if the risk of housing bubbles is evident at the time. Such a behavior by banks would result in the increase in house prices not justifiable by the real sector and their eventual corrections or burst would inflict substantial losses to all sectors of the economy.

However, this behavior will most likely change if a bank adopts the proposed EMM home financing where the rental revenue is tied to a real rental measure and a fair value of the property is used at times of share transfer. Firstly, since the bank is going to share the capital gains or losses from change in value of the property, it would not be so eager to advance financing if there is suspicion of the RE bubbles. Furthermore, the bank's welfare will be in line with the wellbeing of its clients and therefore, under suspicion of housing bubbles, it would recommend them to delay the purchase of homes until the RE prices return to their normal level. Those changes in the behavior of banks would result in cooling down of price boom during upturns and stall the decline in prices during downturns. Consequently, the RE cycle would be smoother. Our simulation results of the two alternative models substantiate these observations. Another important observation from the results is the house prices being lower under the MM home financing. This may be due to the reduction in adverse selection problems.

\subsection{The Reduction in Adverse Selection Problem}

The problem of adverse selection is substantially milder under the MM setting. We could argue in opposition to what is commonly believed that the issue of adverse selection in conventional banking is not always related to problem of asymmetric 
information. Excessive reliance on collateral, motivation for aggressive loan advancement and real possibility of risk transfer do encourage banks to lend to those clients with high risk. However, under the proposed EMM model, the above risk-seeking drivers are absent. As a consequence, the economy stands to benefit.

Even though the mathematical model of the MM presented in the previous sections does not incorporate most of the qualitative aspects of an ideal MM home financing, it incorporates some key features related to collateralization. Since the bank cannot use the client's share as collateral to cover its loss under the MM setting, it will not take any undesirable risk. Further, since the bank cannot transfer away loan to a third party without client's approval, it should be more prudent during the screening process. All of these could result in much reduction in the adverse selection problems.

\subsection{Preventing Formation of Real Estate Bubbles}

Less fluctuating RE price fluctuation and lower price inflation could mean much lower chances of RE bubble formation. This means that that the RE bubble formation and its magnitudes can be greatly subdued by the introduction of the EMM home financing. Accordingly, the negative impact resulting from bursting of such bubble on the economy can be largely avoided. As noted earlier, the bursting of RE bubbles can be damaging to the economy twice the size of the damage from bursting of equity bubbles (Helbling \& Terrones, 2003).

All in all, there are many benefits to the economy from adoption of the EMM model. To sum, these benefits include reduction in house price inflation, stability in the RE prices and, most importantly, less likelihood of RE bubble formation. Prevention of the RE bubbles can significantly increase confidence in the strength of the economy and foster uninterrupted real economic activities.

\section{LIMITATIONS AND SUGGESTIONS FOR FUTURE RESEARCH}

We admit that the models presented here are by no means comprehensive and do not consider all aspects of home financing industry, let along other aspects of the economy. However, we also believe that our assumptions are realistic enough to demonstrate the influences of Conventional vs. EMM financing on real estate prices. Nevertheless, further extension of this work is possible in many respects.

First, one may consider incorporating a more realistic assumption about household income. There are two aspects that stand out. Firstly, the assumption of uniform distribution is less realistic and it is adopted for the sake of simplicity. A more realistic assumption would be a normal distribution or even a positively skewed one. Second, the models do not impose restriction on the minimum income requirement to qualify for home financing. In our models, we assume that any household can move from top of the distribution to its bottom and vice versa. But, in reality, income mobility is very lengthy and slow process. Therefore, reconsidering income mobility and imposing some lower bounds on the income level for home financing qualification as actually practiced by bankers could be more realistic.

The models can also be enhanced by adding more fundamental variables related to the demand and supply of housing. Economic aspects of housing rather 
than its financing aspects could be more important in price discovery. Inclusion of household income as only the fundamental variable could be considered as oversimplifying assumption. Inclusion of other fundamental variables, such as cost of production and down-payment requirements can make the results more robust and reliable.

Finally, based on our previous suggestion of including more fundamental variables, a more realistic simulation of the model could be conducted by using actual historical data. As one alternative, house prices for a group of counties can be simulated using available historical data on income, rental, construction cost and other relevant variables. The resulting outcome under the proposed EMM model can be tested and compared to those from the Conventional home financing.

\section{CONCLUSION AND POLICY RECOMMENDATIONS}

Interest based financial system is believed to be the culprit behind the 20072008 Subprime Crisis. Many economies of the world are still suffering from the consequences of the crisis. This event has reopened grounds for consideration of other financing alternatives as a solution for ill-ridden conventional system. Because of its rapid development and persistent returns, Islamic finance has emerged as a viable alternative. Many researchers argue in favor of the Islamic finance as being more efficient and resilient in times of economic and financial turmoil. Among many justifications of this argument, the Islamic finance's closer ties to the real sector of economy and the profit and loss sharing principle are oft-cited. Unfortunately, the lack of in-depth theoretical research especially in Islamic home financing leaves those arguments as unproven hypotheses or even as mere conjectures.

In this work, we make a humble contribution in this area of research by comparing the impacts that an PLS based Musharakah Mutanaqisah (EMM) home financing and conventional housing loan have on real estate prices. Two alternative rational expectation based multi-period profit maximization models are formulated and simulated. The simulation results have provided support for the comparative advantage of EMM home financing over its conventional counterpart.

There are some important implications obtained from the above analysis. Most notably, the application of the EMM home financing results in substantial smoothening of the RE cycle and contributes to reduction in house price inflation, when compared to the conventional model. Consequently, the probability of real estate bubble formation is substantially less under the EMM setting. Such effect can be explained by the profit and loss sharing nature of the EMM home financing model. Furthermore, the drop in the amount of home financing under the EMM setting coupled with the increased risk sharing responsibility of the bank may also suggest that the adverse selection problem could significantly reduce. Despite some simplifying assumptions used in the models, the practical implications drawn from their outcomes are still valid. The robustness of the simulation results under the EMM setting is further confirmed after relaxing our assumptions about constancy of rental payments as well as financing costs.

In summary, this paper has offered a theoretical proof in support of Islamic finance's resilience to economic shocks and its countercyclical nature. More 
specifically, it has demonstrated that the benefit of a true PLS based Islamic finance product to the economy can be considerable, unlike the conventional case. Another indirect implication of our finding is that, for more efficient functioning of an Islamic finance product, it should be Shari'ah complaint not only in form but in substance as well. Therefore, as the most important policy recommendation for those authorities who are considering adoption of Islamic financing alternative, we would suggest ensuring the existence of PLS feature in the products being considered and the full application of such features in practice such that their economic benefits can be fully materialized.

\section{REFERENCES}

Abdul Razak, D., \& Amin, H. (2013). Application of Musharakah Mutanaqisah Home Financing As an Alternative to Traditional Debt Financing: Lessons Learned From the U.S. 2007 Subprime Crisis. Journal of Islamic Economics, Banking and Finance, 9(3), 115-130.

Al-Zuhaili, W. (2003). Financial Transactions in Islamic Jurisprudence, Vols. 1-2. (M. A. El-Gamal, Ed.). Damascus: Dar al-Fikr al-Muaasir.

Beck, T., Demirgüç-Kunt, A., \& Merrouche, O. (2013). Islamic vs. conventional banking: Business model, efficiency and stability. Journal of Banking $\mathcal{E}$ Finance, $37,433-447$.

Bendjalali, B., \& Khan, T. (1995). Economics of Diminishing Musharakah. Jeddah: Saudi Arabia: Islamic Research and Training Institute.

Bernanke, B., Gertler, M., \& Gilchrist, S. (1999). The Financial Accelerator in a Quantitative Business Cycle Framework *. In J. B. Taylor \& M. Woodford (Eds.), Handbook of Macroeconomics (Vol. 1C, pp. 1341-93). New York: Elsevier Science--North Holland.

Borio, C., Furfine, C., \& Lowe, P. (2001). Procyclicality of the financial system and financial stability : issues and policy options (BIS Papers No. 1).

Chapra, M. U. (2011). The global financial crisis: Some suggestions for reform of the global financial architecture in the light of Islamic finance. Thunderbird International Business Review, 53(5), 565-579.

Ebrahim, M. S., \& Hussain, S. (2010). Financial development and asset valuation: The special case of real estate. Journal of Banking $\mathcal{E}$ Finance, 34 (150-162).

Ebrahim, M. S., Shackleton, M. B., \& Wojakowski, R. M. (2011). Participating mortgages and the efficiency of financial intermediation. Journal of Banking $\mathcal{E}$ Finance, 35, 3042-3054.

Hassan, M. K., \& Kayed, R. N. (2009). The Global Financial Crisis, Risk Management and Social Justice in Islamic Finance. ISRA International Journal of Islamic Finance, 1(1), 33-58.

Helbling, T., \& Terrones, M. (2003). Real and Financial Effects of Bursting Asset Price Bubbles. IMF World Economic Outlook, (April), 61-94.

Hott, C. (2011). Lending behavior and real estate prices. Journal of Banking $\mathcal{E}$ Finance, 35, 2429-2442.

Iacoviello, M. (2005). House prices, borrowing constraints, and monetary policy in the business cycle. The American Economic Review, 95, 739-764. 
Ibrahim, M. H. (2016). Business cycle and bank lending procyclicality in a dual banking system. Economic Modelling, 55, 127-134.

Iqbal, Z., \& Mirakhor, A. (2011). The Stability of the Islamic Financial System. In An introduction to Islamic finance: Theory and practice (pp. 137-149). Wiley.

Kiyotaki, N., \& Moore, J. (1997). Credit cycles. The Journal of Political Economy, 105, $211-248$.

Meera, A. K. M., \& Abdul Razak, D. (2005). Islamic home financing through musharakah mutanaqisah and al-bay bithaman ajil contract: A comparative analysis. Review of Islamic Economics, 9(2), 5-30.

Meera, A. K. M., \& Abdul Razak, D. (2009). Home Financing through the Musharakah Mutanaqisah Contracts: Some Practical Issues. J.KAU: Islamic Econ., 22(1), 121-143.

Mian, A., \& Sufi, A. (2014). House of debt: How they (and you) caused the Great Recession, and how we can prevent it from happening again. USA, Chicago: The University of Chicago Press.

Smolo, E., \& Hassan, M. K. (2011). The potentials of musharakah mutanaqisah for Islamic housing finance. International Journal of Islamic and Middle Eastern Finance and Management, 4(3), 237-258.

Sommervoll, D. E., Borgersen, T. A., \& Wennemo, T. (2010). Endogenous housing market cycles. Journal of Banking and Finance, 34(3), 557-567.

Sun, X., \& Tsang, K. P. (2017). What Drives the Owner-Occupied and Rental Housing Markets? Evidence from an Estimated DSGE Model. Journal of Money, Credit and Banking, 49(2-3), 443-468.

Taipalus, K. (2006). A Global House Price Bubble? Evaluation Based on a New RentPrice Approach. SSRN Electronic Journal. Retrieved from http://www.ssrn.com/ abstract $=1018329$

Usmani, M. T. (2007). An Introduction to Islamic Finance. Karachi: Maktaba Ma'rifatul Quran. Retrieved from http://muftitaqiusmani.com/en/books/PDF/ An Introduction To Islamic Finance/An_Introduction_to_Islamic_Finance.pdf 
This page is intentionally left blank 